\title{
Pasture production responses to fertiliser on renovated West Coast pakihi soils
}

\author{
J.D. MORTON ${ }^{1}$ and A.H.C. ROBERTS ${ }^{2}$ \\ ${ }^{1}$ AgResearch, Invermay Agricultural Centre, PB 50034, Mosgiel \\ ${ }^{2}$ Ravensdown Fertiliser Co-Operative Ltd., Box 608, Pukekohe \\ ants.roberts@ravensdown.co.nz
}

\begin{abstract}
Mowing trials were carried out to determine the rates of fertiliser nitrogen $(\mathrm{N})$, phosphorus $(\mathrm{P})$, potassium $(\mathrm{K})$ and sulphur $(\mathrm{S})$ and frequency of application of $\mathrm{K}$ for maximum pasture production on extremely infertile humped and hollowed pakihi soils in the Grey Valley (Souters and Sommervilles dairy units), and flipped soils at Cape Foulwind (Bassetts dairy unit) under high annual rainfall $(2000-3000 \mathrm{~mm})$ on the West Coast. In the first measurement year, there was no significant increase in pasture production above $480 \mathrm{~kg} \mathrm{~N} / \mathrm{ha}, 56 \mathrm{~kg} \mathrm{P} / \mathrm{ha}, 360$ $\mathrm{kg} \mathrm{K} / \mathrm{ha}$ and $136 \mathrm{~kg} \mathrm{~S} / \mathrm{ha}$ at Souters and Bassetts and a significant increase in pasture production up to $600 \mathrm{~kg}$ $\mathrm{N} / \mathrm{ha}, 56 \mathrm{~kg} \mathrm{P} / \mathrm{ha}, 360 \mathrm{~kg} \mathrm{~K} / \mathrm{ha}$ and $140 \mathrm{~kg} \mathrm{~S} / \mathrm{ha}$ at Sommervilles. In the second year, there was no significant pasture production increase above $480 \mathrm{~kg} \mathrm{~N} /$ ha, $56 \mathrm{~kg} \mathrm{P} / \mathrm{ha}, 360 \mathrm{~kg} \mathrm{~K} / \mathrm{ha}$ and $136 \mathrm{~kg} \mathrm{~S} / \mathrm{ha}$ at all sites. The high N, K and S rates were required because nutrients were not being recycled through returned clippings. This situation would be similar to the early stages of dairy management on these units where only a small proportion of pasture would receive recycled nutrients through return of excreta. Over time, a larger proportion of the pasture would be affected by excreta and fertiliser nutrient requirements would be expected to decrease. There was no increase in pasture production from applying potassium chloride in more than four applications per year at Souters and Bassetts in the first year, but a significant increase in pasture production from eight compared with four applications per year at Sommervilles, where soil QT (quick test) K levels were lower than at the other two sites.
\end{abstract}

Keywords: flipped, hump and hollowed, nitrogen, phosphorus, potassium, sulphur

\section{Introduction}

The fertiliser nutrient required in the greatest quantity for pasture growth in the surface soil of flipped and humped and hollowed pakihi land will be $\mathrm{N}$, both initially and until organic matter is built up. This is caused by burial of the thin veneer of existing fertility during renovation, a complete lack of organic matter in the new surface soil of sand, gravel and structureless sub-soil, a time lag of 2-3 years before a significant proportion of renovated area is affected by nutrient return as dung and urine (During 1984) and the absence of earthworms and micro-organisms to incorporate dung $\mathrm{N}$ into the soil. Accumulation of soil organic matter and availability of nutrients will be maximised from growing as much pasture as possible and the consequent recycling of nutrients through the soil-pasture-animal pathway (Sears 1953). Theoretically, for an annual pasture yield of $12 \mathrm{t} \mathrm{DM/ha,} \mathrm{up} \mathrm{to} 500 \mathrm{~kg} \mathrm{~N} / \mathrm{ha}$ may be required (to achieve $3.5-4.0 \% \mathrm{~N}$ in grasses) as the $\mathrm{N}$ supply to grasses from clover fixation increases over the first 3 years as urine and dung patches cover more of the pasture.

This paper presents results from a 3 year trial which had the following objectives:

1. To determine the rate of fertiliser $\mathrm{N}$, and associated $\mathrm{P}$, $\mathrm{K}$, and $\mathrm{S}$, required to maximise pasture production on pakihi soils that have been humped and hollowed and/ or flipped.

2. To measure the effect of frequency of application of $K$ fertiliser on pasture production.

\section{Materials and Methods \\ Sites}

Small plot sites were selected in paddocks on each of three Landcorp dairy farms representing a range of surface layer materials: Bassetts at Cape Foulwind (flipped sand), Sommervilles at Mawheraiti (humped gravel/compact fine silt) and Souters at Nelson Creek (humped stone/ fine gravel/compact silt). Pastures were established in autumn 2002 with the application of $750 \mathrm{~kg} /$ ha pakihi starter mix (containing P, S, copper, molybdenum), 500 $\mathrm{kg} / \mathrm{ha} 30 \% \mathrm{~K}$ super, $2 \mathrm{t} / \mathrm{ha}$ dolomite, $7.5 \mathrm{t}$ lime/ha and 60 $\mathrm{kg} / \mathrm{ha}$ of urea.

Initial soil tests showed that $\mathrm{pH}$ was adequate and Olsen P low at Souters but adequate at Sommervilles and Bassetts (Table 1). Quick test (QT) K, magnesium $(\mathrm{Mg})$ and calcium $(\mathrm{Ca})$ levels were low at all sites while sulphate-S levels were adequate but organic-S (OS) low at all sites (Table 1). Anion storage capacity (ASC) was low to medium at Souters and Sommervilles but low at Bassetts and tetra phenyl boron K (TBK) and total N levels were low at all sites (Table 1).

\section{Treatments and measurements}

The nutrients $\mathrm{P}, \mathrm{K}$ and $\mathrm{S}$ were applied at each $\mathrm{N}$ application as triple superphosphate (TSP), potassium chloride $(\mathrm{KCl})$ and gypsum $\left(\mathrm{CaSO}_{4}\right)$ to maintain pasture 
Table 1 Initial soil test results at each site.

\begin{tabular}{lcccccccccc}
\hline Site & $\mathrm{pH}$ & $\begin{array}{c}\mathrm{P} \\
(\mu \mathrm{g} / \mathrm{ml})\end{array}$ & QTCa & QTK & QTMg & $\begin{array}{c}\text { Sulph-S } \\
(\mathrm{ppm})\end{array}$ & $\begin{array}{c}\text { Org-S } \\
(\mathrm{ppm})\end{array}$ & $\begin{array}{c}\text { ASC } \\
(\%)\end{array}$ & $\begin{array}{c}\text { TBK } \\
(\mathrm{me} \%)\end{array}$ & $\begin{array}{c}\text { Total N } \\
(\mathrm{ppm})\end{array}$ \\
\hline Souters & 5.6 & 12 & 3 & 1 & 2 & 18 & 3 & 42 & 0.3 & 0.12 \\
Sommervilles & 6.0 & 31 & 5 & 2 & 6 & 14 & 2 & 31 & 0.5 & 0.20 \\
Bassetts & 6.3 & 34 & 2 & 1 & 3 & 20 & 2 & 25 & 0.3 & 0.04 \\
Target range & $5.8-6.0$ & $20-30$ & $5-7$ & $5-8$ & $8-10$ & $10-12$ & $15-20$ & & $>0.8$ & $0.6-1.0$ \\
\hline
\end{tabular}

$\mathrm{P}, \mathrm{K}$ and $\mathrm{S}$ contents at optimum levels of $0.4 \%, 2.8 \%$ and $0.3 \%$. A basal magnesium oxide rate of $110 \mathrm{~kg} / \mathrm{ha}$ was applied to each treatment in August of each year. A regular application of gypsum was used to ensure an adequate $\mathrm{S}$ supply to pasture. Plot size was $5 \times 1 \mathrm{~m}$ running down the slope of each hump $(12 \%)$ and reconstructed dune $(5 \%)$. There were four replicates of each treatment.

The treatments are listed below as the annual rate of nutrient applied:

$1.0 \mathrm{~kg} \mathrm{~N} / \mathrm{ha}, 32 \mathrm{~kg} \mathrm{P} / \mathrm{ha}, 224 \mathrm{~kg} \mathrm{~K} / \mathrm{ha}$ and $80 \mathrm{~kg} \mathrm{~S} / \mathrm{ha}$ applied in four equal applications (Sep, Nov, Jan and Mar) - based on an estimated annual production of 8 t DM/ha.

2. $120 \mathrm{~kg} \mathrm{~N} / \mathrm{ha}, 42 \mathrm{~kg} \mathrm{P} / \mathrm{ha}$ applied in three equal applications (Aug, Nov and Mar) and $315 \mathrm{~kg} \mathrm{~K} / \mathrm{ha}$ and $105 \mathrm{~kg} \mathrm{~S} / \mathrm{ha}$ applied in five equal applications (Aug, Oct, Nov, Jan and Mar) - based on an estimated annual production of $10.5 \mathrm{t} \mathrm{DM} / \mathrm{ha}$.

$3.240 \mathrm{~kg} \mathrm{~N} / \mathrm{ha}, 48 \mathrm{~kg} \mathrm{P} / \mathrm{ha}, 336 \mathrm{~kg} \mathrm{~K} / \mathrm{ha}$ and $120 \mathrm{~kg} \mathrm{~S} /$ ha applied in six equal applications (Aug, Sept, Oct, Dec, Feb, Apr) - based on an estimated annual production of $12 \mathrm{t} \mathrm{DM} / \mathrm{ha}$.

4. $480 \mathrm{~kg} \mathrm{~N} / \mathrm{ha}, 56 \mathrm{~kg} \mathrm{P} / \mathrm{ha}, 360 \mathrm{~kg} \mathrm{~K} / \mathrm{ha}$ and $136 \mathrm{~kg} \mathrm{~S} /$ ha applied in eight equal applications (Aug, Sep, Oct, Nov, Dec, Feb, Mar, Apr) - based on an estimated annual DM production of $13 \mathrm{t} \mathrm{DM} / \mathrm{ha}$.

$5.600 \mathrm{~kg} \mathrm{~N} / \mathrm{ha}, 60 \mathrm{~kg} \mathrm{P} / \mathrm{ha}, 360 \mathrm{~kg} \mathrm{~K} / \mathrm{ha}$ and $140 \mathrm{~kg} \mathrm{~S} /$ ha applied in 10 equal applications (Aug, Sep, Oct, Nov, Dec, Jan, Feb, Mar, Apr, May) - based on an estimated annual DM production of $13 \mathrm{t} \mathrm{DM} / \mathrm{ha}$.

In addition, the effect of frequency of application of $\mathrm{N}, \mathrm{P}, \mathrm{K}$ and $\mathrm{S}$ for the $240 \mathrm{~kg} \mathrm{~N} / \mathrm{ha}$ treatment (likely to be a maintenance $\mathrm{N}$ rate once soil organic matter levels increase) was investigated by the inclusion of two extra treatments:

6. $240 \mathrm{~kg} \mathrm{~N} / \mathrm{ha}, 48 \mathrm{~kg} \mathrm{P} / \mathrm{ha}, 336 \mathrm{~kg} \mathrm{~K} / \mathrm{ha}$ and $120 \mathrm{~kg} \mathrm{~S} /$ ha applied in eight equal applications (Aug, Sep, Oct, Nov, Dec, Feb, Mar, Apr).

7. $240 \mathrm{~kg} \mathrm{~N} / \mathrm{ha}, 48 \mathrm{~kg} \mathrm{P} / \mathrm{ha}, 336 \mathrm{~kg} \mathrm{~K} / \mathrm{ha}$ and $120 \mathrm{~kg} \mathrm{~S} /$ ha applied in four equal applications (Sept, Nov, Feb, Apr).

Plots were excluded from grazing and clippings were removed so the nutrient responses could be measured on pasture where no nutrients are being recycled, since a large proportion of new pasture will not be affected by excretal return in the initial years. This necessitated the need for complete replacement of the $\mathrm{P}, \mathrm{K}$ and $\mathrm{S}$ removed in clippings which required high rates, especially of $\mathrm{K}$, to be applied.

Measurements were taken of:

1. Pasture production from pre-mowing rising plate readings (10 per plot) before each fertiliser application.

2. Species composition from each plot in September, January and April of each year.

3. Soil tests for $\mathrm{pH}, \mathrm{P}, \mathrm{K}, \mathrm{S}, \mathrm{Mg}, \mathrm{Ca}$ on each plot every March.

\section{Results and Discussion \\ Soil test levels}

Most soil test levels were in the target range for pasture production (Table 2). The exceptions were low soil sulphate-S levels at Souters, low Olsen P and QTK levels at Sommervilles and low QTCa at Bassetts. Soil S levels at Souters would be expected to be higher because the site had the highest initial ASC, and organic-S levels were similar to the other sites. Bassetts would receive some $\mathrm{S}$ from rainfall that would compensate for its lower ASC as it is within $10 \mathrm{~km}$ of the coast.

At Sommervilles and Bassetts, soil QTK levels were significantly lower at the higher rates of $\mathrm{N}$, suggesting that the rate of $\mathrm{K}$ applied was insufficient to replace that removed in the clippings. There was a similar effect for $\mathrm{Mg}$ at Sommervilles. Soil Olsen P levels increased from the second year at Sommervilles and Bassetts which suggested that the rate of $\mathrm{P}$ applied was too high for maintenance of Olsen P levels at these sites.

At any one site, soil test levels were similar among the treatments, which indicated that there was equal opportunity for each rate of $\mathrm{N}$ to be expressed in pasture production.

\section{Pasture production}

In the first year at Souters and Bassetts, there was a significant increase in pasture production up to the 480 $\mathrm{kg} \mathrm{N} / \mathrm{ha} / \mathrm{yr}$ treatment while at Sommervilles there was a further significant response up to $600 \mathrm{~kg} \mathrm{~N} / \mathrm{ha} / \mathrm{yr}$ (Table 3 ). The efficiency of response decreased slightly as $\mathrm{N}$ rate increased at all sites, although there was a low efficiency of response to fertiliser treatments containing 120 and $240 \mathrm{~kg} \mathrm{~N} / \mathrm{ha} / \mathrm{yr}$ at Bassetts. There was no significant response to frequency of $\mathrm{K}$ fertiliser 


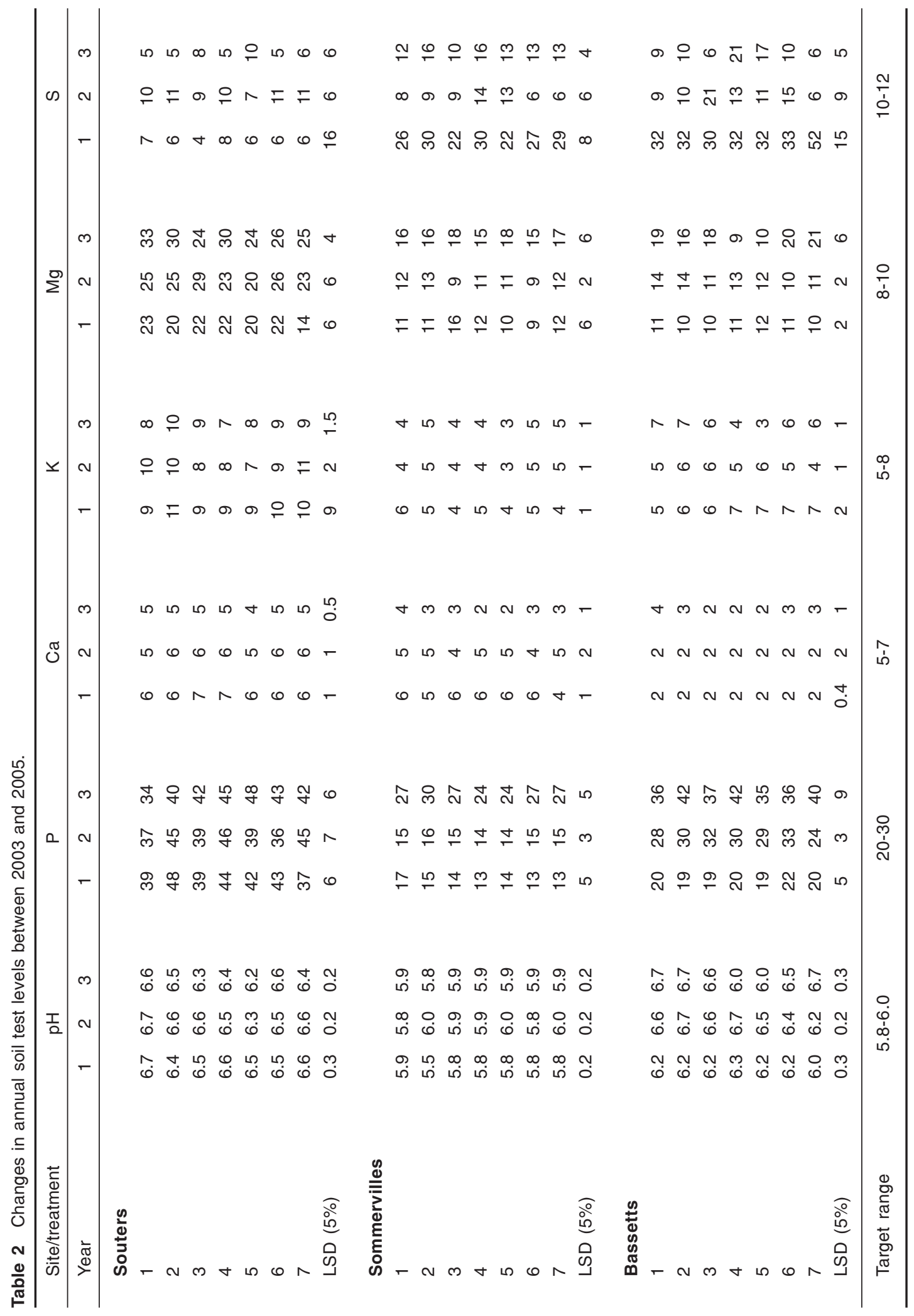


Table 3 Effect of fertiliser treatments on pasture production ( $\mathrm{kg} \mathrm{DM} / \mathrm{ha})$ and efficiency of $\mathrm{N}$ response $(\mathrm{kg} \mathrm{DM} / \mathrm{kg}$ N) in Year $1(2002 / 2003)$.

\begin{tabular}{lcccccc}
\hline \multirow{2}{*}{ Treatment } & \multicolumn{2}{c}{ Souters } & \multicolumn{2}{c}{$\begin{array}{c}\text { Sommervilles } \\
\text { Production }\end{array}$} & Efficiency & \multicolumn{2}{c}{ Bassetts } \\
& Production & Efficiency \\
\hline 1 & 5218 & & 7722 & & 5921 & \\
2 & 6787 & 13 & 10158 & 20 & 6139 & 2 \\
3 & 8134 & 12 & 10549 & 12 & 6742 & 3 \\
4 & 10429 & 11 & 12712 & 10 & 10117 & 9 \\
5 & 10993 & 10 & 14443 & 11 & 10544 & 8 \\
6 & 7894 & 11 & 11093 & 14 & 8003 & 9 \\
7 & 8144 & 12 & 9856 & 9 & 7950 & 9 \\
LSD (5\%) & 722 & & 945 & & & \\
\hline
\end{tabular}

Table 4 Effect of fertiliser treatment on pasture production ( $\mathrm{kg} \mathrm{DM} / \mathrm{ha}$ ) and efficiency of response ( $\mathrm{kg} \mathrm{DM} / \mathrm{kg} \mathrm{N}$ ) in Year $2(2003 / 2004)$.

\begin{tabular}{lcccccc}
\hline \multirow{2}{*}{ Treatment } & \multicolumn{2}{c}{ Souters } & \multicolumn{2}{c}{ Sommervilles } & \multicolumn{2}{c}{$\begin{array}{c}\text { Bassetts } \\
\text { Production }\end{array}$} \\
& Prodficiency \\
\hline 1 & 8424 & 7 & 6383 & & 8390 & \\
2 & 9252 & 7 & 8208 & 15 & 9384 & 8 \\
3 & 9844 & 6 & 7918 & 6 & 9616 & 5 \\
4 & 10667 & 5 & 9308 & 6 & 11185 & 6 \\
5 & 10460 & 3 & 9740 & 6 & 10939 & 4 \\
6 & 9459 & 4 & 7329 & 4 & 10288 & 8 \\
7 & 9704 & 5 & 7952 & 7 & 10301 & 8 \\
LSD (5\%) & 675 & & 765 & & 1073 & \\
\hline
\end{tabular}

Table 5 Effect of fertiliser treatment on pasture production $(\mathrm{kg} \mathrm{DM} / \mathrm{ha})$ and efficiency of $\mathrm{N}$ response $(\mathrm{kg} \mathrm{DM} / \mathrm{kg}$ $\mathrm{N})$ in Year $3(2004 / 2005)$.

\begin{tabular}{lcccccc}
\hline \multirow{2}{*}{ Treatment } & \multicolumn{2}{c}{ Souters } & \multicolumn{2}{c}{$\begin{array}{c}\text { Sommervilles } \\
\text { Production }\end{array}$} & Efficiency & \multicolumn{2}{c}{ Bassetts } \\
& Production & Efficiency & 4719 & & 3536 & \\
\hline 1 & 2780 & & 5060 & 3 & 3794 & 2 \\
2 & 3233 & 4 & 5989 & 3 & 4236 & 3 \\
3 & 3843 & 4 & 7223 & 5 & 6046 & 5 \\
4 & 4102 & 3 & 8042 & 6 & 4196 & 3 \\
5 & 4248 & 2 & 5430 & 3 & 4534 & 4 \\
6 & 3356 & 2 & 5975 & 5 & 721 & \\
7 & 3260 & 2 & 539 & & &
\end{tabular}

application at Souters and Bassetts, but at Sommervilles pasture production was significantly higher from eight compared to four applications (Table 3).

These results can be discussed in relation to the soil test levels for the very mobile nutrient K. At Souters, soil QTK levels were above the optimal range (5-8) and the presence of adequate soil $\mathrm{K}$ ensured that there was no advantage in pasture production from more than four applications of fertiliser. Sommervilles had soil QTK levels below the optimum range resulting in less available $\mathrm{K}$, and hence a greater frequency of application of $\mathrm{K}$ increased pasture production.

In the second year, there was a significant increase in pasture production up to the fertiliser treatment containing $480 \mathrm{~kg} \mathrm{~N} / \mathrm{ha}$ at all sites (Table 4). The efficiency of response to the $\mathrm{N}$ fertiliser was lower than in the first year, especially at Souters and Sommervilles, and again decreased as the rate of fertiliser $\mathrm{N}$ increased. There were no significant differences in pasture production from different frequencies of $\mathrm{K}$ application at any of the sites (Table 4).

The greater production from $0 \mathrm{~N}$ in the second compared with the first year at Souters and Bassetts and the lesser response to $\mathrm{N}$ at these sites could be because of the build-up of soil organic $\mathrm{N}$ from decaying clover nodules and roots.

Pasture production in the third and final year at both Souters and Bassetts was lower than in Year 2 because of porina damage (Table 5). There were significant increases in pasture production up to $240 \mathrm{~kg} \mathrm{~N} / \mathrm{ha}$ at Souters and $480 \mathrm{~kg} \mathrm{~N} / \mathrm{ha}$ at Sommervilles and Bassetts but the efficiency of response was lower than in the 
Figure 1 Pasture composition at Souters in April/May of each year under different fertiliser treatments (kg N/ ha/yr).
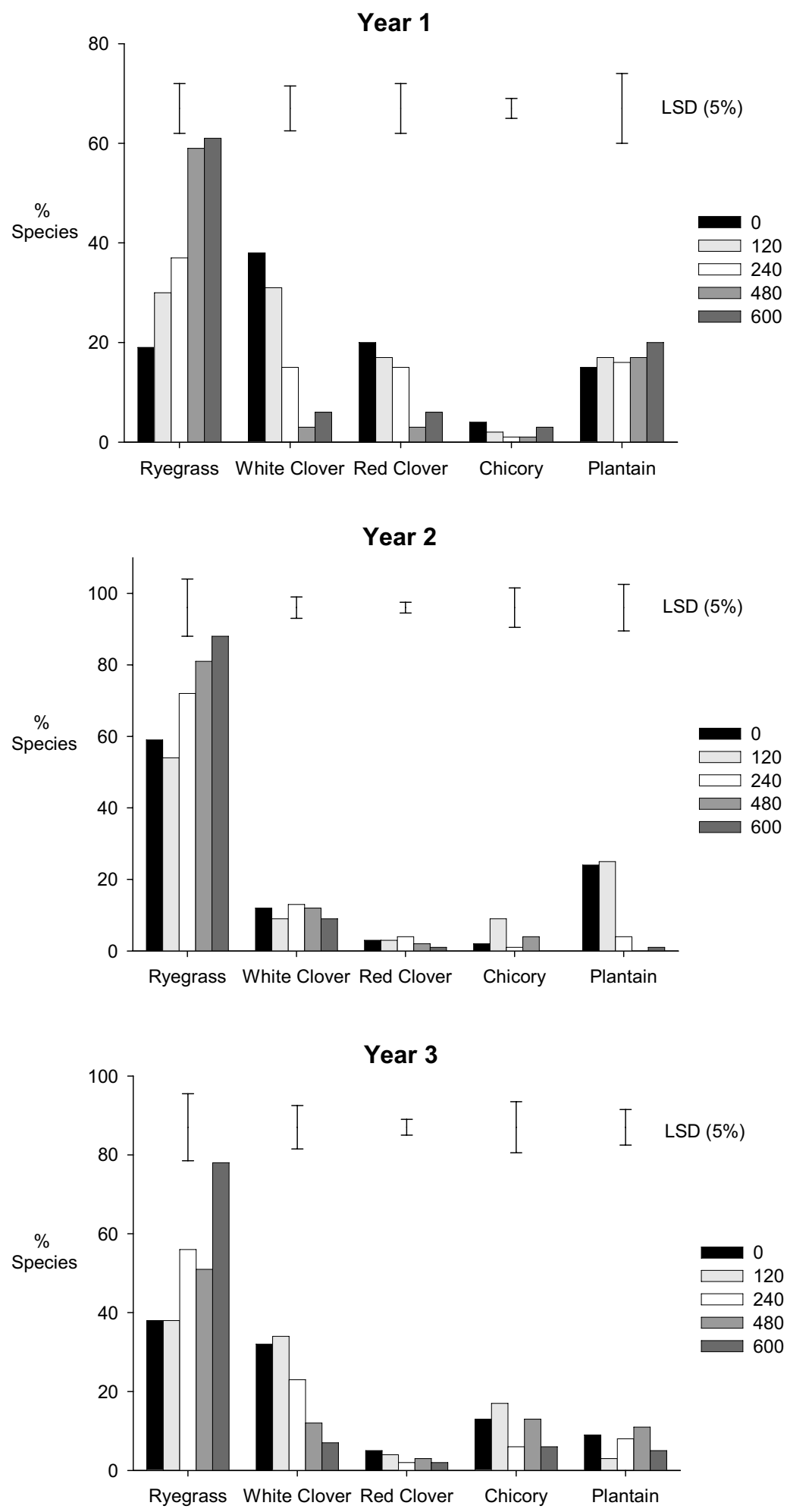
Figure 2 Pasture composition at Sommervilles in April/May of each year under different fertiliser treatments (kg N/ha/yr).
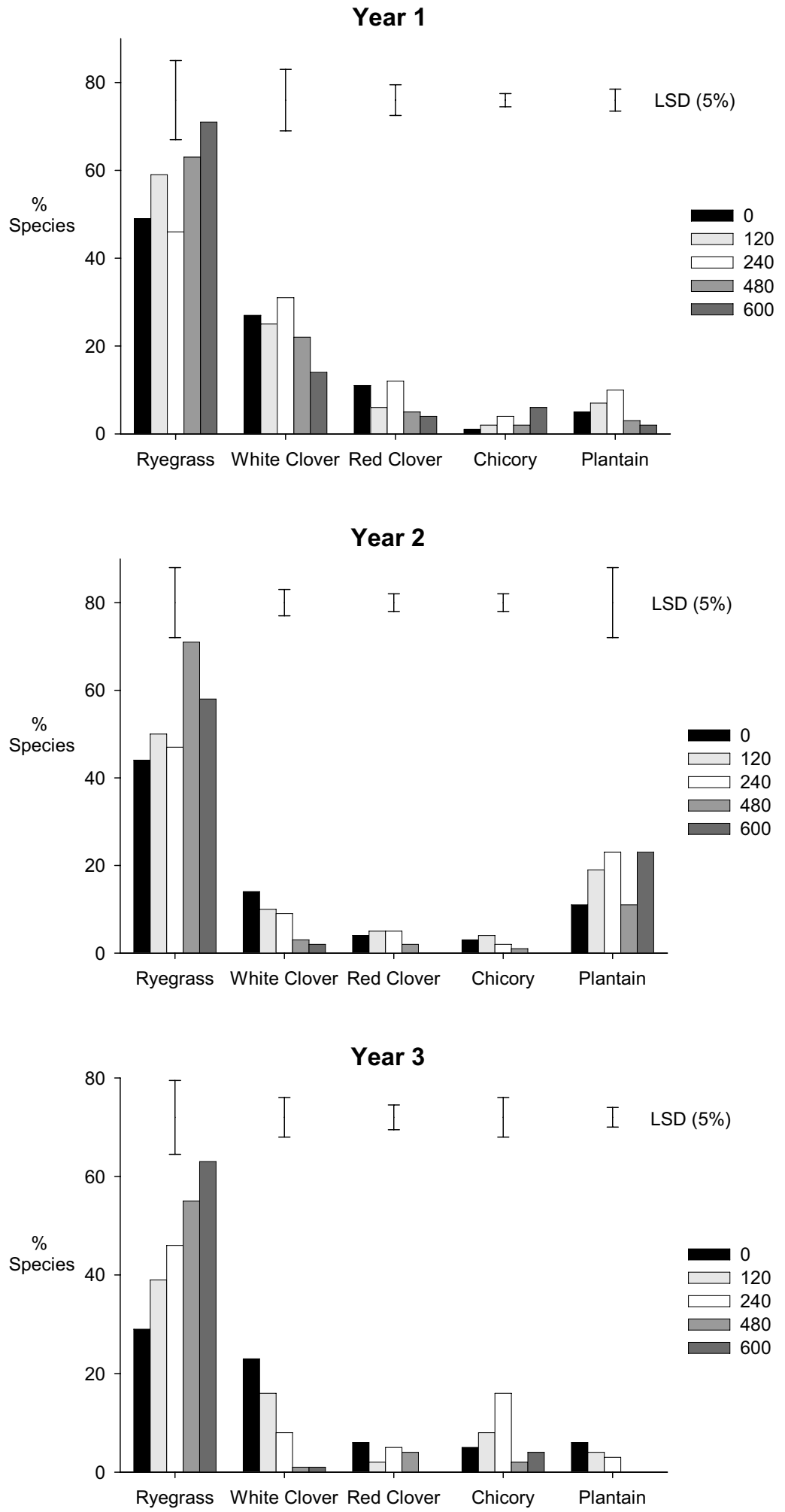
Figure 3 Pasture composition at Bassetts in April/May of each year under different fertiliser treatments (kg N/ ha/yr).

Year 1

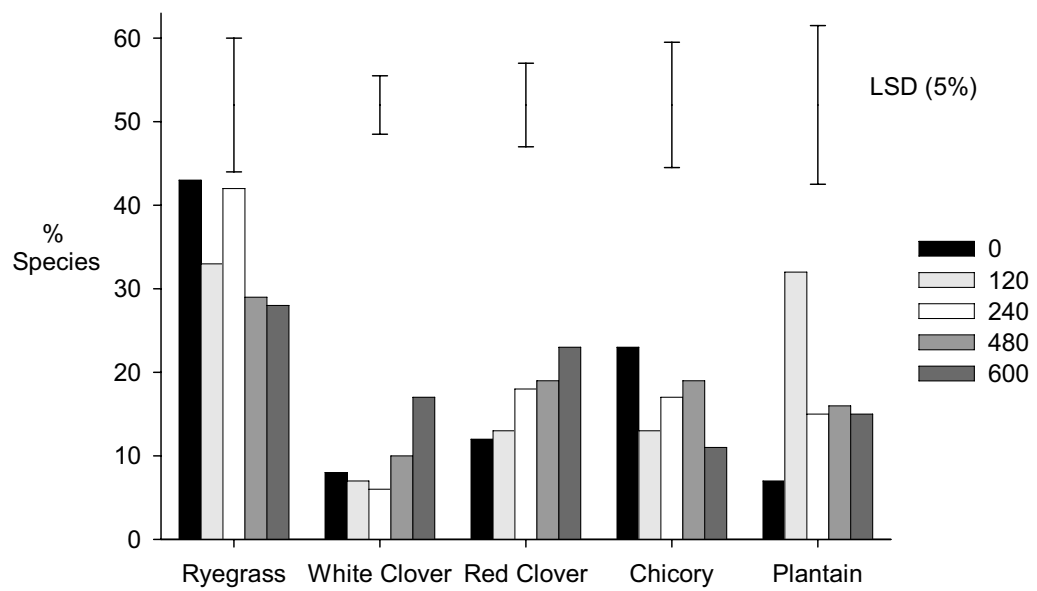

Year 2

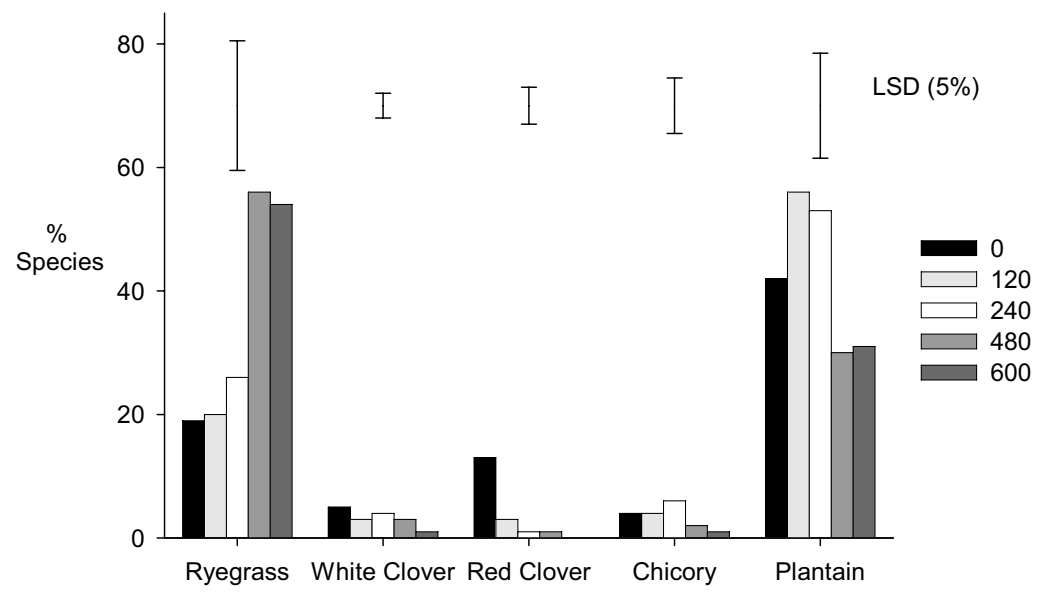

Year 3

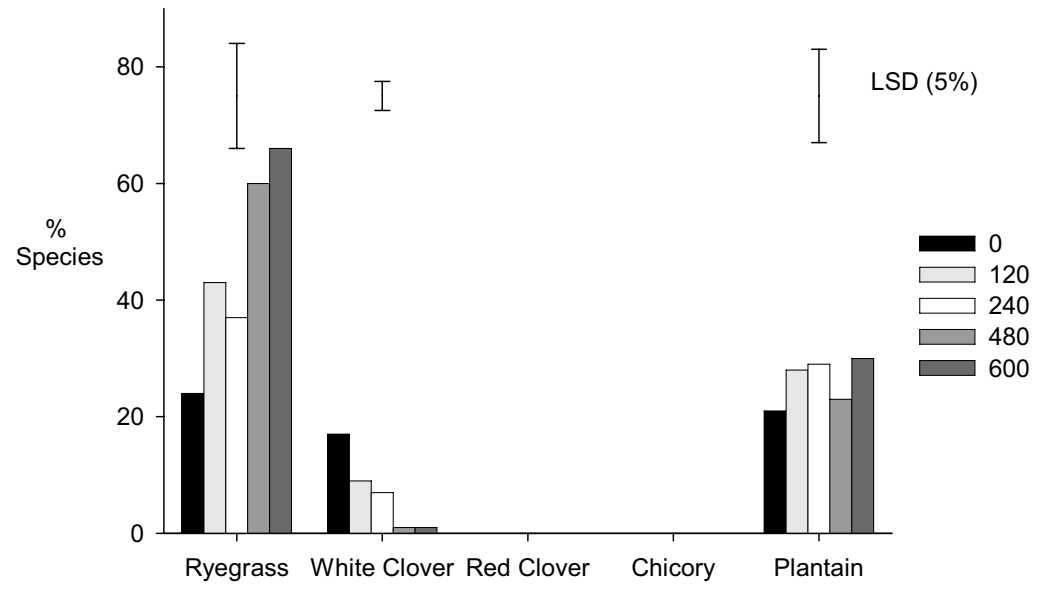


previous 2 years. There was a significant increase in pasture production from four and six compared with eight applications of fertiliser at Sommervilles but no significant difference at the other two sites.

\section{Pasture composition}

The pasture composition, measured in April/May, at each site for each year is shown in Figures 1,2 and 3. Similar trends to April/May were evident in the September and January pasture composition measurements (data not shown).

Generally, ryegrass content increased and red and white clover decreased as the amount of $\mathrm{N}$ applied increased for each of the 3 years at each site. The exception was in the first year at Bassetts (Fig. 3) where, unlike the other two sites (Figs. 1 \& 2), ryegrass content decreased while white and red clover content tended to increase as the rate of $\mathrm{N}$ applied increased. However, this trend reversed in the second and third years of the trial (Figs. $2 \& 3$ ). Plantain content was low, except at Souters in Year 1, and at Bassetts for all 3 years, and did not differ greatly with rate of $\mathrm{N}$. Chicory content was greatest at Bassetts in Year 1 but had disappeared by Year 3, and did not differ with fertiliser treatment.

There was no consistent difference in the effect of frequency of fertiliser application on pasture composition at any of the sites (data not shown).

\section{Conclusions and Recommendations}

The following rates of nutrients should be applied for the immediate post-establishment phase (up to 2-3 years after establishment) for optimum pasture production on humped and hollowed and flipped land from pakihi soils:

$240-480 \mathrm{~kg} \mathrm{~N} / \mathrm{ha} / \mathrm{yr}$

$56 \mathrm{~kg} \mathrm{P} / \mathrm{ha} / \mathrm{yr}$

$125 \mathrm{~kg} \mathrm{~S} / \mathrm{ha}$ (30 kg elemental S/ha)/yr

$100 \mathrm{~kg} \mathrm{Mg} / \mathrm{ha} / \mathrm{yr}$

In the case of $\mathrm{K}$, the cycling under dairy cow grazing is more efficient than under no clippings returned or $\mathrm{N}$ because of the longer duration of response in the urine patch (Morton 1984). Therefore the high rates of up to $360 \mathrm{~kg} \mathrm{~K} / \mathrm{ha} / \mathrm{yr}$ in the trial are greater than would be required for grazed paddocks. Drawing from previous trial results and experience on the West Coast, 100-150 $\mathrm{kg} \mathrm{K} / \mathrm{ha} / \mathrm{yr}$ would be recommended. Ongoing monitoring of soil QTK levels every year, so that the rate of K applied maintains soil QTK levels in the target 5-8 range is recommended. This would also apply to soil test $\mathrm{P}, \mathrm{Mg}, \mathrm{Ca}$ and $\mathrm{S}$ levels. Pasture analysis can also be used.

There is no need for more than four applications of $\mathrm{K}$ fertiliser per year, and, as the soils develop over time, less frequent applications of K fertiliser may be sufficient, although this will need to be tested by further trials.

The authors realise that the recommendations for $\mathrm{N}$ and $\mathrm{P}$, while satisfying the agronomic demands of the improved pastures on renovated soils, may clash with regional environmental imperatives and may have to be tempered accordingly.

\section{ACKNOWLEDGEMENTS}

The authors thank Elliott Scott, Richard Fowler, Sue Smith and Shelley Eccles for their technical assistance. Landcorp and Ravensdown jointly funded the research.

\section{REFERENCES}

During, C. 1984. Fertilisers and Soils in New Zealand Farming. Government Printer. Wellington.

Morton, J.D. 1984. The spatial distribution of excreta and its contribution to soil fertility. New Zealand Ministry of Agriculture and Fisheries Internal Report. Sears, P.D. 1953. Pasture growth and soil fertility. I. The influence of red and white clovers, superphosphate, lime and sheep grazing, on pasture yields and botanical contribution. New Zealand Journal of Science and Technology 35A(1): 1-29. 